\title{
Fresh Milk Quality Analysis of Buffalo, Cow, Goat And Sheep of Sunwal Municipality (West), Nepal
}

\author{
Deepak Kumar Shrestha*
}

\begin{abstract}
In the present study, the fresh raw milk of four different mammals viz, buffalo, goat, cow and sheep were collected from village area of Sunwal Municipality and analyzed for their physio-chemical parameters viz, moisture, conductivity, $p H$, titratable acidity specific gravity, fat solids not fat and total solid. It was found that all measured parameters were found as per recommended standard as compared with reported nutritional quality of milk from WHO standards and other International Standards. The main objective of this study was to compare the physio-chemical properties and quality parameters of different fresh milk samples available in Sunwal Municipality, Nawalparasi (West), Nepal and provide nutritional benefits for health. These tests were carried in chemistry laboratory of Butwal Multiple Campus and Dairy Devlopment Corporation in Butwal industrial area. The value of $\mathrm{pH}$ ranged from $6.58 \pm 0.53$ to $6.65 \pm 0.51$, conductivity ranged from $6.52 \pm 1.98$ to $10.8 \pm 2.07 \mathrm{mS}$, moisture content ranged from $78.1 \pm 4.30 \%$ to $89.7 \pm 5.02 \%$. Similarly TTA\% ranged averagely from $0.117 \%$ to $0.153 \%$, CLR from 26.1 to 28.3 , specific gravity ranged from 1.0261 to 1.0283 averagely and fat \% ranged from $3.3 \pm 0.41 \%$ to $6.8 \pm 0.96 \%$. Similarly, SNF\% ranged from $1.58 \pm 0.49 \%$ to $2.05 \pm 0.22 \%$ and $T S \%$ ranged from $11.225 \pm 0.28 \%$ to $16.075 \pm 1.19 \%$ respectively.
\end{abstract}

Keywords: Physicochemical parameters, titratable acidity, solids Not Fat, raw milk, total solid

\section{Introduction}

Milk is an important source of all basic nutrients required for mammals including human beings. Milk is a complex colloidal solution (emulsion) containing fat globules, casein micelle and whey proteins in aqueous solution of lactose, minerals and few other minor compounds. Milk is the characteristic secretion of mammary glands of all mammals. In 2011, FAO estimate $85 \%$ of all milk worldwide was produced from cow, about $11 \%$ by buffaloes, $2 \%$ by goats, $1.4 \%$ by sheep and $0.2 \%$ by camels. So cow's milk dominates commercial production worldwide.

* Lecturer in Chemistry Butwal Multiple Campus T.U. Email: shresthadeepak854@gmail.com, Contact no. : 9847043953 
Fresh milk contains all the essential nutrients as lactose, fat, protein, minerals and vitamins in balanced ratio rather than other food ( Hossain et al., 2013). The average composition of fresh milk is water $87.20 \%$, dry matter $12.80 \%$ (fat $3.70 \%$, Protein $3.50 \%$, Lactose 4.90\% and Ash 0.70\%) ( Byron et al., 1974). The important research has been carried out to determine different physio-chemical parameters of raw milk by different renowned researchers of different countries.

Kanwal et al., have found lactometer reading within the range of 26 to 30 (where buffalo has 27.65, cow 30.00, goat 28.05 and sheep has 28.05), \%TTA within the range of 0.11 to 0.19 (where buffalo has 27.65 , cow 0.15 , goat 0.135 and sheep has 0.181 ), Specific gravity within the range of 1.02 to 1.03 (where buffalo has 1.02, cow 1.03, goat 1.02 and sheep has 1.02), Fat\% within the range of 4 to 9.6 (where buffalo has 5.52, cow 4.56, goat 4.73 and sheep has 8.96 ), \% SNF within the range of 8.28 to 10.14 (where buffalo has 8.79 , cow 9.17 , goat 8.92 and sheep has 71 ), \% TS within the range of 12.73 to 19.50 (where buffalo has 14.04, cow 13.73, goat 13.55 and sheep has 18.53)

Similarly, Mohmood et al., (Pak. J. Nutr., 9(12): 1192-1197, 2010) have found the pH ranges from 6.49 to 6.90 where buffalo has $6.75 \pm 0.15$, cow has $6.64 \pm 0.02$, goat has 6.55 \pm 0.06 and sheep has $6.63 \pm 0.04)$.

According to Mohammad et al., (2008) the $\mathrm{pH}$ ranges from 6 to 7.47 (where buffalo has $6.93 \pm 0.57$, cow has $6.67 \pm 0.51$ and goat has $6.59 \pm 0.59$ ), conductivity ranges from 4.9 to 12.8 (where buffalo has6.55 \pm 1.56 , cow has $9.20 \pm 1.95$ and goat has $10.8 \pm 2.07$ ), and moisture\% ranges from 72.1 to 91.82 (where buffalo has $76.4 \pm 4.30$, cow has $86.8 \pm 5.02$ and goat has $80.5 \pm 4.66$ ).

According to Minard et al., (Penn State Univ. Department of Chemistry, USA 1990) moisture in range of $90.6 \%$ to $82.6 \%$, casein in the range of $2.0 \%$ to $5.5 \%$, fat in range of $1.1 \%$ to $6.5 \%$ and lactose in the range of $4.5 \%$ to $7 \%$ among horse, cow, human, goat and sheep where horse has max. \% of moisture (90.6) while sheep has lowest(82.6). Similarly $\%$ fat is max .in sheep (6.5) while cow has minimum fat (3.9).

Milk from various mammals such as human, cow, buffalo, goat, sheep, camel etc. are used for different nutritional purposes such as feeding to young ones and preparation of some nutritional products such as milk cream, butter, yogurt, ghee, cheese, ice milk, sour milk, hot chocolate, pudding etc. (Webb et.al., 1974 Hassan, 2005). Consumers always demand nutritionally enriched milk and dairy products (Kamao et al., 2007). Early lactation milk contains colostrums, which carries the mother's antibodies to its young and can reduce the risk of many diseases. Interspecies consumption of milk is not uncommon, particularly among humans, many of whom consume the milk of others mammals (Bhatia et al., 2015). 
As an agricultural product, milk is extracted from non human mammals during or soon after pregnancy. India is the world's largest producer of milk, The United State, India, China and Brazil are the world's largest exporters of milk and milk products. Throughout the world, more than six billion people consume milk and milk products. Over 750 million people live in dairy farming households. (Bhatia et al., 2015).

Mammals consume milk in the nutritionally significant weeks following birth. Whole milk contains vitamins (principally thiamin, riboflavin, pantothenic acid and vitamins $\mathrm{A}, \mathrm{D}$, and $\mathrm{K}$ ), minerals (calcium, potassium, sodium, phosphorus, and trace metals), proteins (which includes all the essential amino acids), carbohydrates (chiefly lactose) and lipids (fat). The only important elements in which milk is seriously deficient are iron and vitamin C. Infants are usually born with storage supply of iron large enough to meet their needs for several weeks. Vitamin C is easily secured through an orange juice supplement.

Pouch milk is pasteurized milk while fresh (raw) milk is not pasteurized milk. Pasteurization is used to kill harmful pathogenic bacteria by heating the milk for a short time and then immediately cooling it. A side effect of the heating of pasteurization is that some vitamins and mineral contents are lost. The main objectives of this study is to determine some of physico-chemical characteristics of different raw milk, to compare quality of milk from different mammals, to give baseline information regarding for human consumption and to find out the benefits of milk for human health. The significances of the study are: to find out the addition of water or other components which carry poor quality milk, to improve farming and marketing technology for milk and to take step against selling of poor quality of milk.

\section{Methods and Materials}

\section{Research Methodology}

The first preliminary survey had been carried out for the selection of study sites to collect fresh milk samples. After fixing the study sites, the fresh milk samples were collected. The following quality parameters of each fresh milk sample had been analyzed, they are; $\mathrm{pH}$, conductivity, moisture, TTA, CLR, specific Gravity, fat, SNF and TS.

\section{Site Map of Study Area}

My study site is villege area of Sunwal Municipality. It lies in Nawalparasi (West) district of Lumbini province of Nepal. Its geographical coordinates are $27.63^{\circ}$ latitude $83.65^{\circ}$ longitude. This study is designed to determine the physicochemical properties fresh milk of different mammals in Sunwal Municipality. 


\section{Samples Collection}

Total sixteen fresh raw milk samples of cow, goat, buffalo and sheep, four samples of each species were collected from village area of Sunwal Municipality in the morning by direct milking from individual household farm. Milk samples of $200 \mathrm{ml}$ were taken through homogenizing using sterile polythene bottles and stored in ice box and brought in BMC and DDC laboratories. The samples were analysed within 4 hours of collection.

\section{Data collection, Analysis and Interpretation}

The primary data were collected from lab after the experimentation and observation. The analysis was done as per Steel and Torrie (1980), using Completely Randomized Design (CRD). The raw data were edited properly, organized in the form of tables and later on calculation was done and the results were again tabulated. The data were analyzed using appropriate statistical tools such as bar diagram, line graph pie chart etc.

Table 1: Methods used for data Analysis

\begin{tabular}{|l|l|}
\hline Parameters & Methods Employed \\
\hline Moisture & Gravimetric Method \\
\hline pH & Auto digital pH meter (HI 98107, HANA Romania) \\
\hline Conductivity & Conductance measurement (by CM- 611-E-M.s Electronics) \\
\hline$\%$ TTA & Zero set Burette Meter Method (Re-affirmed 2003) \\
\hline CLR & Lactometer \\
\hline$\%$ Fat & Modified Gerber Method \\
\hline$\%$ SNF & Richmond's Method \\
\hline$\% \mathrm{TS}$ & Fat $\%+$ TS $\%$ \\
\hline
\end{tabular}

\section{Required Chemicals and Reagents}

Phenolphthalein, Sodium hydroxide, Distilled water, Sulphuric acid, Amyl alcohol, 0.1N KCL.

\section{Required Apparatus}

Volumetric flasks, Measuring cylinder, Test tubes, $\mathrm{pH}$ meter, Conductivity meter, Lactometer, Beakers, Flat bottom aluminium dishes, Zero set burette meter, Pipette, Glass rod, Lactometer jar, Butyrometer, Refrigerator, Water bath, Oven, Tripod stand, Spatula etc. 


\section{Physico-Chemical Analysis of Fresh Milk}

Fresh raw milk samples were collected from different local village of Sunwal Municipality. The following parameters were measured for each samples viz; $\mathrm{pH}$, moisture, conductivity, TTA, SNF, TS and fat in laboratories of BMC and DDC in Butwal.

\section{Determination of $\mathrm{pH}$}

Solutions with $\mathrm{pH}$ less than 7.0 are acidic and solutions with $\mathrm{pH}$ greater than 7.0 is basic. Milk is slightly acidic close to neutral $\mathrm{pH}$. The exact value depends on how the milk was processed, how long it was opened or stored. The $\mathrm{pH}$ of the fresh milk samples was determined by using auto digital pH meter (HI 98107,HANA Instruments, Romania).

\section{Measurement of Conductivity}

Conductivity of fresh milk samples was measured by following AOAC (2000) method where conductometer (CM- 611-E-M.s Electronics) was used. Conducto meter was first dipped in KCL solution $(0.1 \mathrm{~N})$ for one hour and washed with distilled water at least 2-3 times. Then the conductivity of fresh milk was calculated directly.

\section{Determination of Moisture Content}

Measuring the moisture content in fresh milk is an important quality control step. Moisture content of milk is the loss in mass of sample on heating about $105 \pm 1^{\circ} \mathrm{C}$ under operating conditions specified (Badami et al., 1984). The moisture content of the milk gives an indication of nutritional value, low moisture content is a requirement for long storage (Aurand et al., 1987).

Moisture content was determined according to the modified method of AOAC (2000)"s methods. Briefly, moisture content was determined by the difference between the known weight of milk sample and determined weight of the total solid after evaporating the liquid component of the milk sample on a hot plate (Imran et al., 2008).

\section{Determination of Total Titratable Acidity (TTA)}

Generally, the acidity of milk means the total acidity (Natural + developed) or titratable acidity. The titratable acidity test measures the amount of alkali which is required to change the $\mathrm{pH}$ of milk from its initial value of about 6.5 to 6.8 , to the $\mathrm{pH}$ of the colour change of phenolphthalein added to milk to indicate the end point ( $\mathrm{pH} \mathrm{8.3).} \mathrm{It} \mathrm{is} \mathrm{determined} \mathrm{by}$ titrating a known volume of milk with standard alkali using phenolphthalein indicator. The total titratable acidity test is a simple acid-base reaction. This test allows a calculation of percentage acidity in milk. 
The process of determination of \%TTA with Zero set burette meter is as follows (Gakkhar et al., 2015):

- $10 \mathrm{ml}$ milk was transferred with the pipette in a beaker.

- 3-4 drops of phenolphthalein indicator solution was added and stirred with glass rod.

- The contents were titrated rapidly with $\mathrm{N} / 10 \mathrm{NaOH}$ solution by the help of Zero set burette meter \& continued to add alkali drop by the drop and stirring the content with glass rod till first definite change to faint pink colour which remain constant for 10 to 15 seconds.

- The burette reading was noted.

- To calculate \%TTA,

- $\mathrm{TTA} \%=$ No. of $\mathrm{ml}$ of $0.1 \mathrm{~N} \mathrm{NaOH}$ solution required for Neutralization $\times 0.09$

\section{Determination of Corrected Lactometer Reading (CLR)}

The lactometer is a special type of hydrometer. Lactometer test is used to determine the density of milk and to know if the milk has been adulterated with added water or solids. The density of fresh raw milk determined which was totally additive free. The lactometer jar should be vertical and the bulb of lactometer should not touch the side. Repeated the reading after depressing the lactometer about $3 \mathrm{~mm}$ and allowing it to come to rest. Noted temperature of milk immediately after taking the lactometer reading . It is generally preferred to take the lactometer reading at $27^{\circ} \mathrm{C}$.

At $27^{\circ} \mathrm{C}$, Lactometer Reading $=$ Corrected Lactometer Reading.

If the temperature is other than $27^{\circ} \mathrm{C}$, then the LR should be corrected to get CLR of milk. Correction table should to be applied to lactometer readings taken at temperature other than $27^{\circ} \mathrm{C}$.

\section{Determination of Specific Gravity}

Specific gravity of milk is the ratio of density of any substance to the density of standard substance (water) at $4^{\circ} \mathrm{C}$.

Specific Gravity of normal milk is 1.028 to 1.302 . Specific gravity of water is 1 , hence addition of water to milk tends to decrease the specific gravity of milk. Fat content reduces the specific gravity since, fat is lighter portion.

After finding the value of CLR, Specific Gravity of fresh milk samples was determined by using,

Specific Gravity $=(C L R \div 1000)+1 \mathrm{~g} / \mathrm{ml}$ (http://ecoursesonline.iasri.res.in) 


\section{Determination of \% Fat}

The fat content of a milk product is an important indication of quality, both economically and physiologically. In the dairy industry, it is mainly determined by using "quick methods Spectrometric measuring methods are often used which is costly. Many laboratories therefore, are using a method developed by the Swiss chemist and dairy-owner Niklsus Gerber, patented in 1891 under the name "Acid Butyrometer". This method was used because it is simple, fast, low-cost and suitable for relatively high sample throughout.

The fat content, determined by Modified Gerber method is as follows:

- A clean and dry butyrometer was taken.10ml sulphuric acid was added with the help pipette.

- $\quad 10 \mathrm{ml}$ of fresh sample milk was measured and transfer it to the butyrometer.

- $1 \mathrm{ml}$ amyl alcohol was transferred with the help of tilt measure.

- The mouth of butyrometer was covered with rubber stopper using stopper key.

- Butyrometer was shaked carefully about $45^{\circ}$ without inverting until the content are mixed and dissolved.

- Butyrometer was transfered into the centrifuge machine for 3 to 5 minutes (1400rpm)

- After centrifuge, butyrometer was kept in water bath at $66^{\circ} \mathrm{C}$.

- $\quad$ Reading was noted. It was percentage of fat.

\section{Determination of Solids- Not-Fat (\% SNF)}

SNF content of milk is related to its fat percentage and specific gravity by the Richmond's formula. Although the only accurate way to determine Solid-non-fat (SNF) content of milk is the gravimetric method, lactometers were used for this purpose. A modified Richmond's formula was used to calculate SNF content of the milk after measuring lactometer reading and fat content (Sebastian et al., 1974).

The \% of SNF and total solids in milk was calculated using the Richmond's formula (Gakkhar et al., 2015)

$\mathrm{SNF}($ in $\%)=\frac{C L R}{4}+0.25 \mathrm{~F} \%+0.44$ (factor)

Where,

$\mathrm{SNF}=$ Solids-not-fat of milk

$\mathrm{F}=$ Fat percentage of milk

$\mathrm{CLR}=$ Corrected lactometer reading (at $27^{\circ} \mathrm{C}$ ). 


\section{Determination of Total Solid (\%TS)}

The total solids content of milk is total amount of materials dispersed in the aqueous phase i.e $\%$ Total Solids $=$ SNF Percentage + Fat Percentage. The only accurate way to determine T.S is by evaporating the water from an accurately weighed sample. However, T.S was estimated from the Corrected Lactometer Reading (CLR)

$\mathrm{T} . \mathrm{S}=\mathrm{SNF} \%+$ Fat $\%$

\section{Data Analysis and Interpretation}

Table 2: Calculation related to moisture content

\begin{tabular}{|l|l|l|}
\hline Fresh milk Sample & Wt. of milk sample $(X)$ & \% moisture content \\
\hline Buffalo & $20 \mathrm{~g}$ & $78.1 \pm 4.30$ \\
\hline cow & $20 \mathrm{~g}$ & $89.7 \pm 5.02$ \\
\hline Goat & $20 \mathrm{~g}$ & $82.3 \pm 4.66$ \\
\hline Sheep & $20 \mathrm{~g}$ & $\mathbf{8 0 . 7} \pm 4.45$ \\
\hline
\end{tabular}

Table 3: Calculation Related to \% TTA

\begin{tabular}{|c|c|c|}
\hline Fresh milk sample & $\begin{array}{l}\text { Volume of NaOH } \\
\text { consumed (Mean) }\end{array}$ & $\begin{array}{l}\text { \%TA }=\mathbf{V} \times \mathbf{0 . 0 9} \\
(\text { Mean })\end{array}$ \\
\hline Buffalo & $1.3 \mathrm{ml}$ & 0.117 \\
\hline Cow & $1.7 \mathrm{ml}$ & 0.153 \\
\hline Goat & $1.6 \mathrm{ml}$ & 0.144 \\
\hline Sheep & $1.8 \mathrm{ml}$ & 0.162 \\
\hline
\end{tabular}

\section{For CLR,}

Since, the lab temperature was $27^{\circ} \mathrm{C}$. So,

Corrected Lactometer Reading $(\mathrm{CLR})=$ Lactometer Reading (LR)

Table 4: Calculation related to Specific Gravity

\begin{tabular}{|c|c|c|}
\hline Fresh milk sources & $\begin{array}{l}\text { Lactometer Reading } \\
\text { (Mean) }\end{array}$ & Sp. Gravity(Mean) \\
\hline Buffalo & 28.3 & $1.0283 \mathrm{~g} / \mathrm{ml}$ \\
\hline Cow & 26.1 & $1.0261 \mathrm{~g} / \mathrm{ml}$ \\
\hline Goat & 26.4 & $1.0264 \mathrm{~g} / \mathrm{ml}$ \\
\hline Sheep & 27.5 & $1.0275 \mathrm{~g} / \mathrm{ml}$ \\
\hline
\end{tabular}


Table 5: Calculation related to \% SNF \% TS

\begin{tabular}{|l|l|l|l|l|}
\hline $\begin{array}{l}\text { Fresh milk } \\
\text { sources }\end{array}$ & $\begin{array}{l}\text { Corrected LR } \\
\text { (Mean) }\end{array}$ & \% of fat & \% of SNF & $\begin{array}{l}\text { \% of Total } \\
\text { Solid (TS) }\end{array}$ \\
\hline Buffalo & $\mathbf{2 8 . 3}$ & $6.8 \pm 0.96$ & $1.8820 \pm 0.32$ & $16.075 \pm 1.19$ \\
\hline Cow & $\mathbf{2 6 . 1}$ & $3.3 \pm 0.41$ & $1.5815 \pm 0.49$ & $11.225 \pm 0.28$ \\
\hline Goat & $\mathbf{2 6 . 4}$ & $4.5 \pm 0.63$ & $1.8816 \pm 0.29$ & $12.725 \pm 0.80$ \\
\hline Sheep & $\mathbf{2 7 . 5}$ & $5.2 \pm 0.56$ & $2.0568 \pm 0.22$ & $14.195 \pm 0.68$ \\
\hline
\end{tabular}

\section{Result and Discussions}

All samples of fresh milk were analyzed by standard procedures as mentioned above. The methods of calculation for each parameter were mentioned above and the result obtained was tabulated below;

Table 6: Quality parameter of different fresh milk sample available in different places of Sunwal Municipality:

\begin{tabular}{|l|l|l|l|l|}
\hline Quality Parameters & Buffalo & Cow & Goat & Sheep \\
\hline pH (Mean) & $6.61 \pm 0.57$ & $6.65 \pm 0.51$ & $6.55 \pm 0.59$ & $6.58 \pm 0.53$ \\
\hline Conductivity & $6 . .97 \pm \mathbf{1 . 5 6}$ & $9.27 \pm \mathbf{1 . 9 5}$ & $10.8 \pm \mathbf{2 . 0 7}$ & $6.52 \pm \mathbf{1 . 9 8}$ \\
\hline Moisture (\%) & $78.2 \pm \mathbf{4 . 3 0}$ & $89.7 \pm \mathbf{5 . 0 2}$ & $82.3 \pm \mathbf{4 . 6 6}$ & $\mathbf{8 0 . 7} \pm \mathbf{4 . 4 5}$ \\
\hline $\begin{array}{l}\text { Total Titratable Acidity } \\
\text { (TTA) (\%) (Mean) }\end{array}$ & 0.117 & 0.153 & 0.144 & 0.162 \\
\hline $\begin{array}{l}\text { Corrected Lactometer } \\
\text { Reading (CLR) (Mean) }\end{array}$ & 28.3 & 26.1 & 26.4 & 27.5 \\
\hline Specific Gravity (Mean) & 1.0283 & 1.0261 & 1.0264 & 1.0275 \\
\hline Fat (\%) & $6.8 \pm 0.96$ & $3.3 \pm 0.41$ & $4.5 \pm 0.63$ & $5.2 \pm 0.56$ \\
\hline Solid Not-Fat (SNF) (\%) & $9.275 \pm 0.32$ & $7.925 \pm 0.49$ & $8.225 \pm 0.29$ & $8.675 \pm 0.68$ \\
\hline Total Solid (TS) (\%) & $16.075 \pm 1.19$ & $11.225 \pm 0.28$ & $12.725 \pm 0.80$ & $14.195 \pm 0.68$ \\
\hline
\end{tabular}

\section{Variation of pH}

Milk is slightly acidic close to neutral. The exact $\mathrm{pH}$ value depends on how the milk was processed, how long it was opened or stored. All the four samples were found acidic or close to neutral having the $\mathrm{pH}$ value range from $6.55 \pm 0.59$ to $6.65 \pm 0.0 .51$. The $\mathrm{pH}$ value of all the samples is tabulated in table 6. Among these samples, Goat milk had the lowest pH (6.55 \pm 0.59$)$ and highest was found in cow (6.65 \pm 0.51$)$. 


\section{Variation of Conductivity}

The results obtained in this study showed that goat milk had the highest EC

10.8 $\pm 2.07 \mathrm{mS}$ followed by cow $9.27 \pm 1.95 \mathrm{mS}$, then buffalo $6.97 \pm 1.56 \mathrm{mS}$ and the sheep milk had the lowest EC of $\mathbf{6 . 5 2} \pm 1.98 \mathbf{~ m S}$. The results obtained in this study were closer to the previous findings from AOAC(2000). The results are shown in the table 6 .

\section{Variation of Moisture}

Moisture content is the quantity of water contained in the material. In the present study, the range of moisture content was from $78.1 \pm 4.30 \%$ to $89.7 \pm 5.20 \%$ as given in the table 6. Among four samples, Buffalo milk had the lowest moisture content $(\mathbf{7 8 . 1} \pm 4.3 \%)$ followed by the sheep milk $(80.7 \pm 4.45)$ then goat milk $(82.3 \pm 4.66 \%)$ and finally, Cow milk had the highest moisture content of $89.7 \pm 5.20 \%$.

\section{Variation of Total Titratable Acidity (TTA)}

In the present study, \% TTA was averagely ranged from $0.117 \%$ to $0.162 \%$ as shown in the table 6. Buffalo milk had the lowest TTA\% (0.117) followed by Goat milk (0.153\%), Cow milk (0.153) and the highest TTA\% was of sheep milk (0.162). The results are further represented in the graph below:

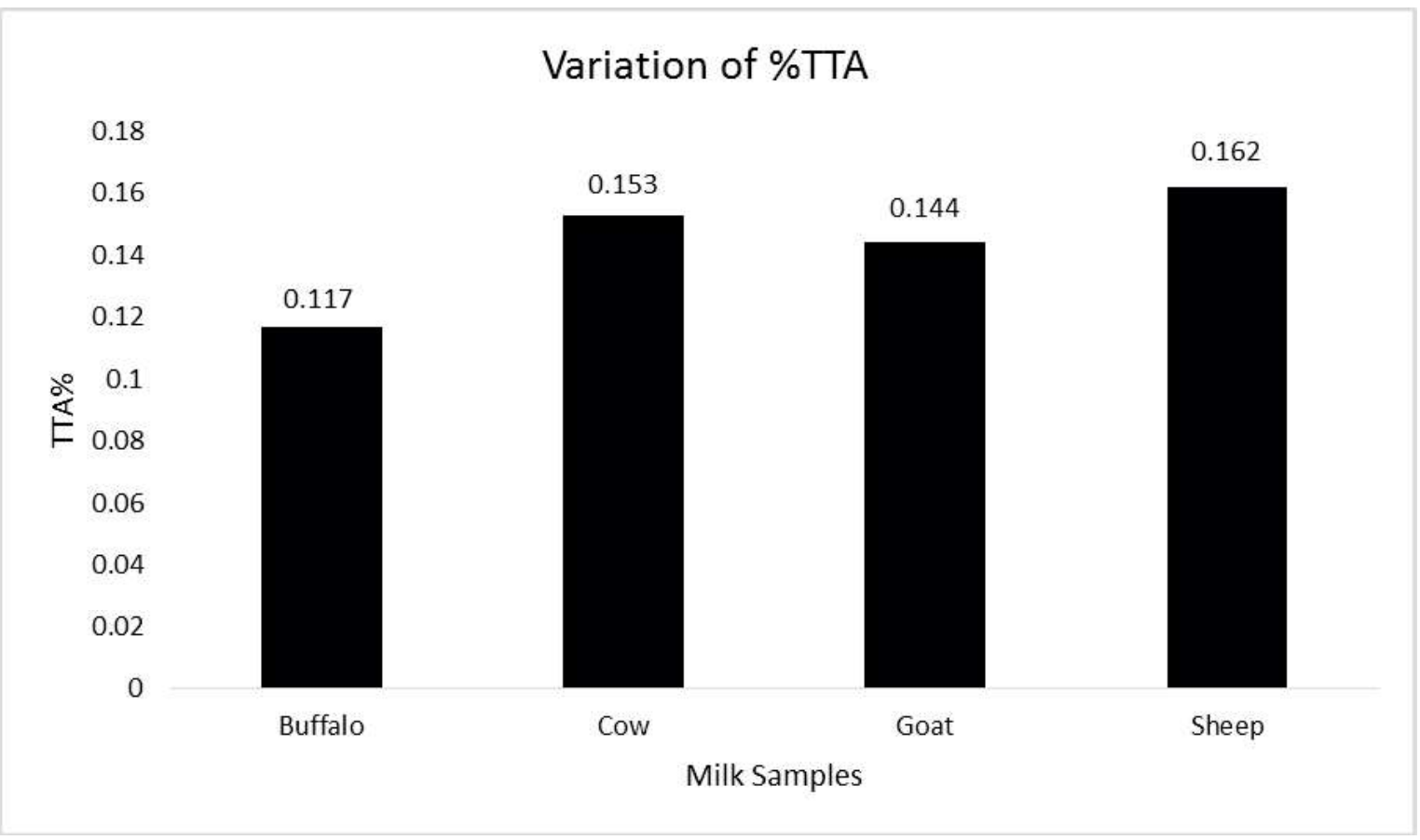

Fig. 4: Variation of \% TTA of different samples of fresh milk 


\section{Variation of CLR}

Lactometer test is used to determine the density of milk and to know if the milk has been adulterated with added water or solids. In the present study, the average range of CLR was found from 26.1 to 28.3 as given in the table 6. Among these four samples Cow milk had the lowest CLR of $\mathbf{2 6 . 1}$ followed by goat milk 26.4, sheep milk 27.5 and Buffalo milk had the highest CLR of 28.3. The results are graphically represented below for further discussion:

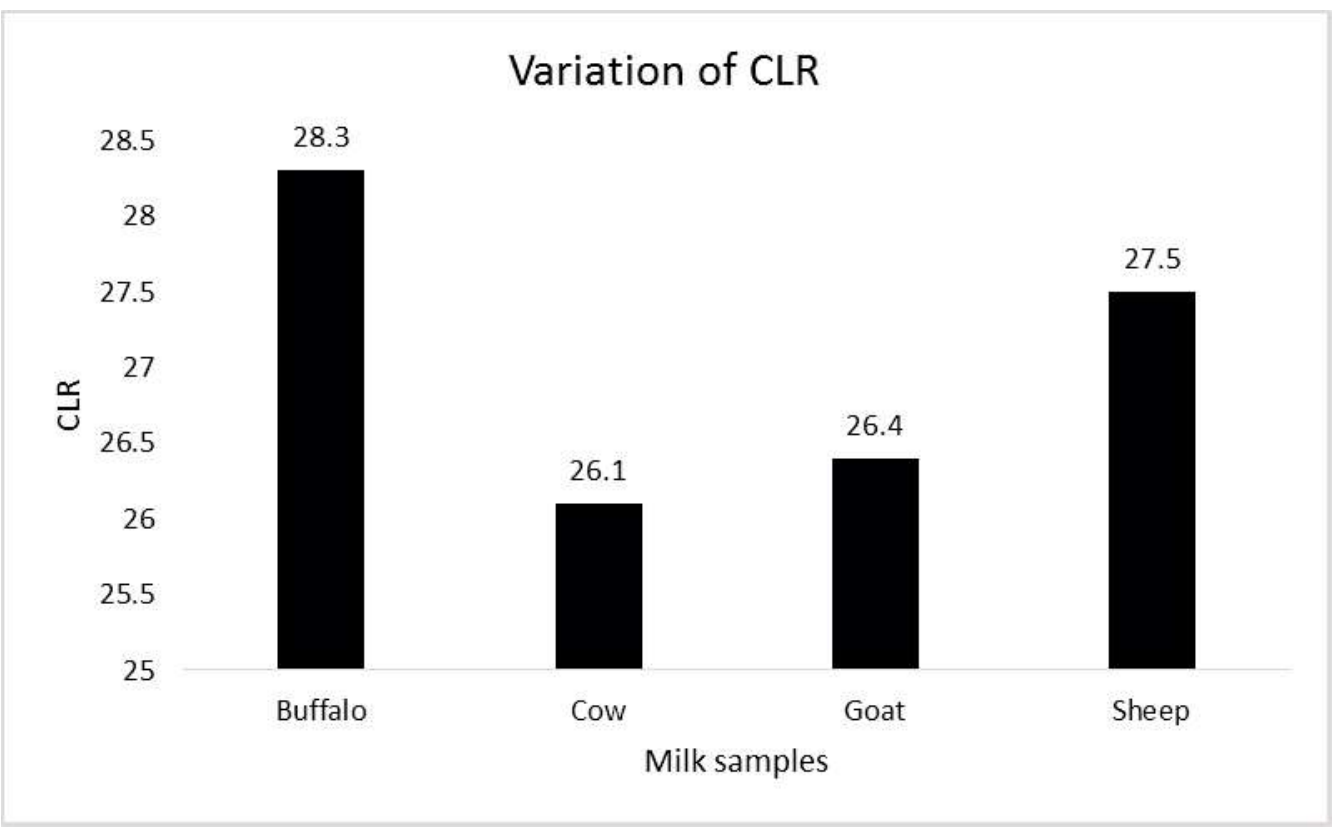

Fig. 5: Graphical Representation of Variation of CLR

\section{Variation of Specific Gravity}

Specific gravity of milk is the ratio of density of any substance to the density of standard substance (water) at $4^{\circ} \mathrm{C}$.

Among four samples, Cow milk had the average lowest specific gravity of $\mathbf{1 . 0 2 6 1} \mathbf{g} / \mathbf{m l}$ followed by goat milk (1.0264 g/ml), Sheep milk (1.0275) and buffalo had the highest specific gravity of $1.0283 \mathrm{~g} / \mathrm{ml}$.

\section{Variation of Fat}

The fat content of milk is an important indication of quality, both economically and physiologically. 
In the present study, percentage of fat content was varied from $3.3 \pm \%$ to $6.8 \pm \%$. Cow milk had the lowest percentage of fat $(3.3 \pm 0.41 \%)$, followed by goat $(4.5 \pm 0.63 \%)$, sheep $(5.2 \pm 0.56 \%)$ and the buffalo milk had the highest fat of $6.8 \pm 0.96 \%$. The results are further represented in the graph below.

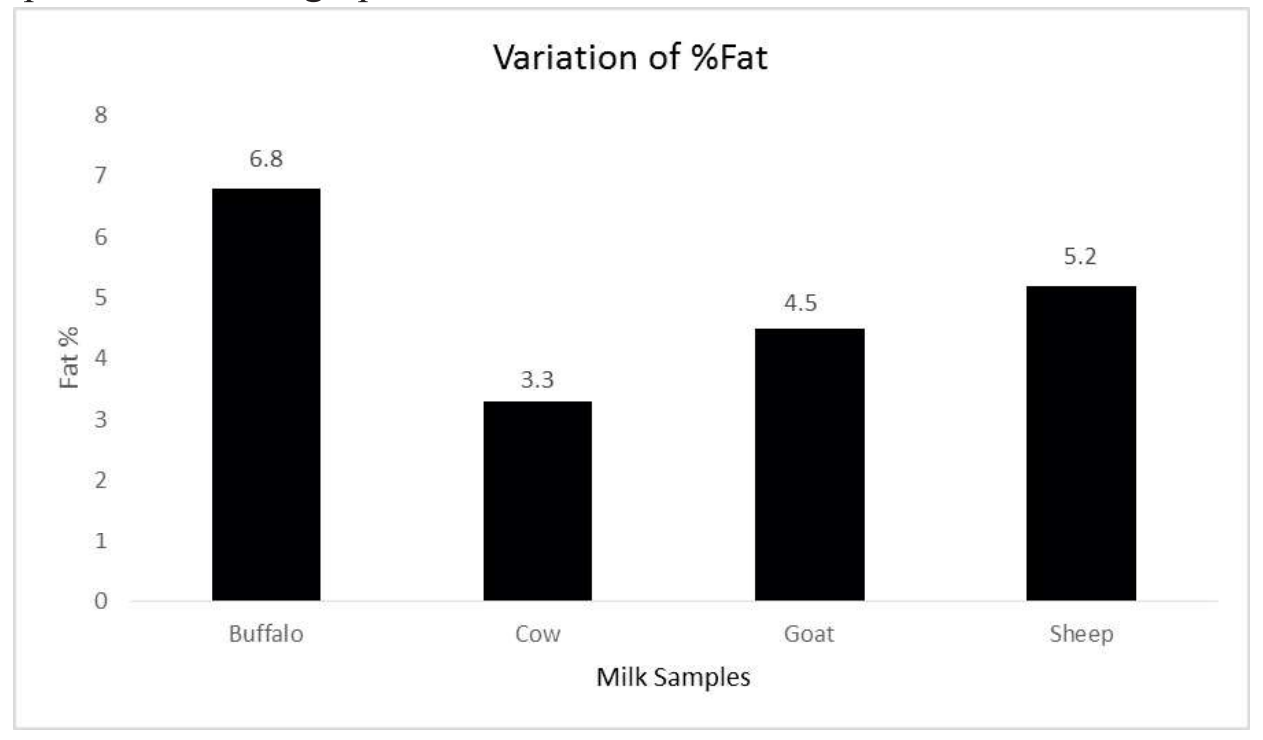

Fig. 7: Graphical representation of variation of fat

\section{Variation of Solids Not-Fat (SNF)}

The result obtained in this study showed that Buffalo milk had the highest \% of SNF of $\mathbf{9 . 2 7 5} \pm 0.32 \%$ followed by sheep milk $(8.675 \pm 0.68 \%)$, Goat milk $(8.225 \pm 0.29 \%)$ and Cow milk had the lowest \%TTA of $7.925 \pm 0.49 \%$.

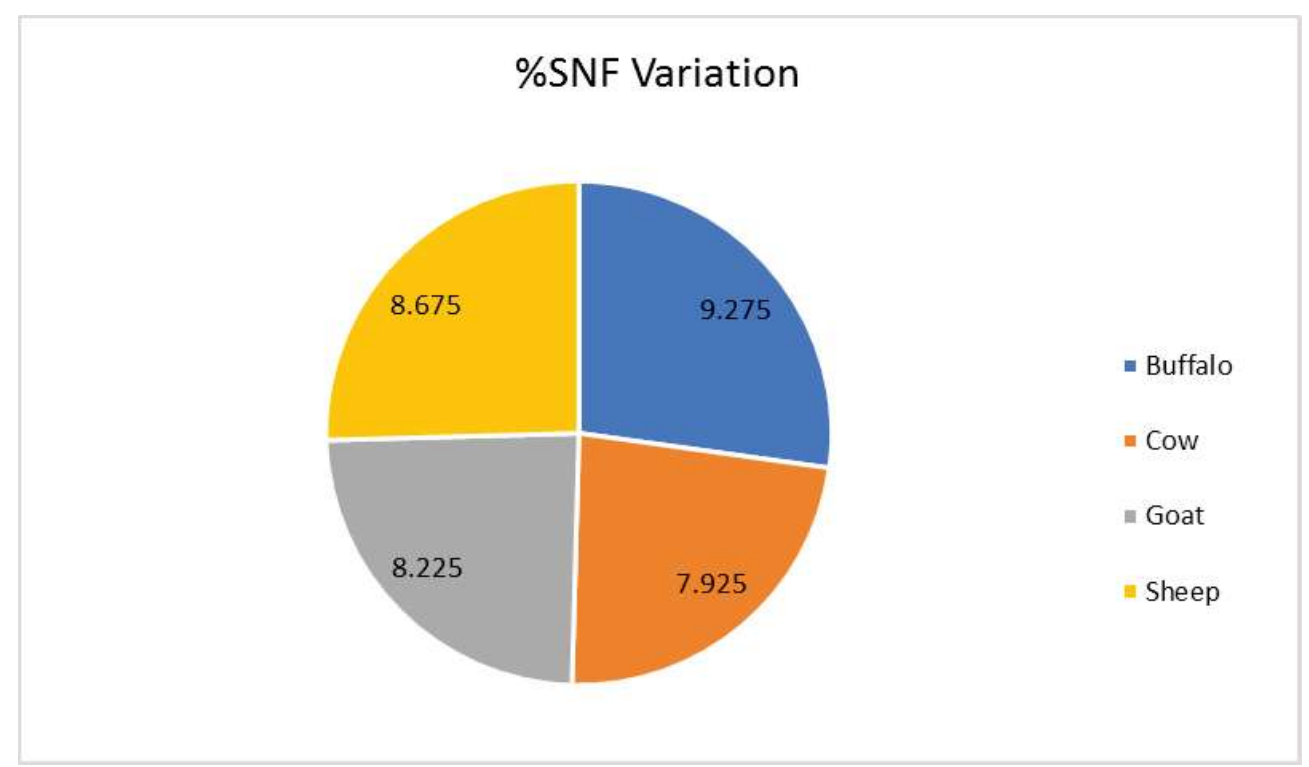

Fig. 8: Variation of \% SNF in different fresh milk samples 


\section{Variation of Total Solid (TS)}

The total solids content of milk is total amount of materials dispersed in the aqueous phase i.e. $\%$ Total Solids $=$ SNF Percentage + Fat Percentage. The Results obtained in this study showed that Buffalo milk had the highest \% TS content of $\mathbf{1 6 . 0 7 5} \pm 1.19 \%$ followed by sheep milk (14.195 $\pm 0.68 \%)$, Goat milk $(12.725 \pm 0.80 \%)$ and Cow milk had the lowest \% TS content of $11.225 \pm 0.28 \%$.

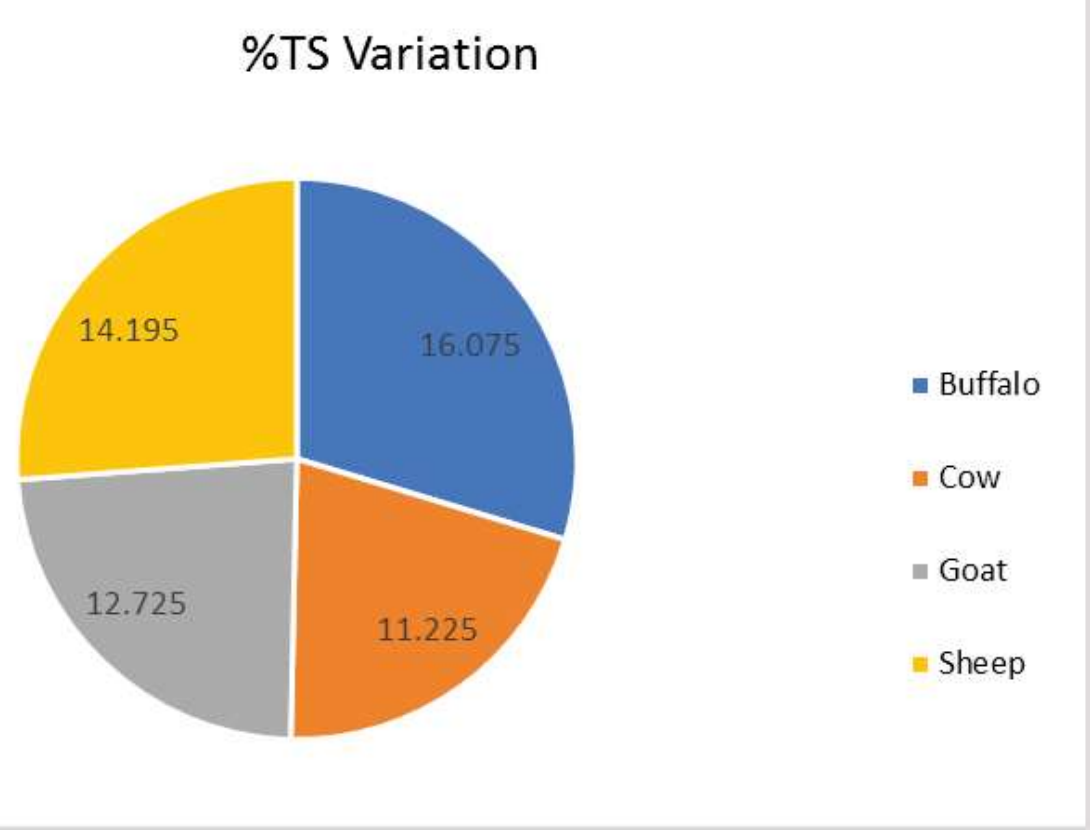

Fig. 9: Pie chart representation of variation of \% TS

\section{CONCLUSION}

In the present study, preliminary investigations were carried out to ascertain the physiochemical characteristics of various fresh milk samples collected from the Sunwal Municipality, (west) Nepal. The study was made with a view to understand and analyse the different constituents of fresh milk and thereby to get possible measures. However more attention should be paid on methodology and learning various ideas and technique regarded with chemicals and instruments.

For the study of chemical and physical properties, fresh milk of different mammals viz: Buffalo, Cow, goat, and Sheep milk were collected. taken as sample $1^{\text {st }}, 2^{\text {nd }}, 3^{\text {rd }}$ and $4^{\text {th }}$ respectively. During the test, 6 different parameters (each parameters were analysed for three times) were checked in laboratory. The conclusion of this research work are as follows : 
Cow milk had the highest moisture content of $89.7 \pm 5.20$ and buffalo milk had the lowest moisture content of $78.1 \pm 4.30 \%$. All these samples were considered to be mildly acidic. Cow milk had the highest $\mathrm{pH}$ content of $6.65 \pm 0.59$ and goat milk had the lowest $\mathrm{pH}$ content of $6.55 \pm 0.59$. Similarly Goat milk had the highest conductivity of $10.28 \pm 2.07 \mathrm{mS}$ and sheep milk had the lowest conductivity of $6.52 \pm 1.98 \mathrm{mS}$. Sheep milk had the highest TTA of $0.162 \%$ and buffalo milk had the lowest TTA of $78.2 \%$. Buffalo milk had the highest fat percentage, CLR, highest SNF, highest TS of $6.8 \pm 0.96,28.3,9.27,16.025 \pm 1.19$. percentage while a cow milk had the lowest fat, CLR ,SNF, TS of 3.3 $\pm 0.41,26.1,7.925,7.925,7.925 \%$ respectively.

The physicochemical parameters of all fresh milk samples are within the recommended values and there is no any problem regarding the quality of fresh milk. The experimental data shows no need to implement common objectives, policies and programs for Improvement in the quality of milk.

The milk with high moisture, low fat, moderate protein is good quality milk and from my study, goat have best quality milk for human consumption because of its low fat, high moisture and enough protein. Based upon availability in market cow milk is good than other because of its high moisture, low fat and moderate protein.

All the type of milk are good for health and have their own health benefits. So, what to consume depends on its availability and our preference. Just make sure that milk is part of our daily diet.

\section{References}

Anonymous, 1967. Pasteurized Milk Ordinance. U.S. Public Health Service, U.S. Dept. of health, Education and Welfare, Pub. 229, Washington DC, U.S.A, pp: 331-333

Anonymous, 1967. U.S. Public Health Service. Pasteurized milk ordinance. Public Health Service, US Dept. health, Education and Welfare, Pub. 229, Washington DC, USA, pp: 331-333.

AOAC (Association of Official and Analytical Chemists) Official Methods of analysis $17^{\text {th }}$ Ed. Washington DC: AOAC; 2000.

Athar, I.H. and Ali, 1986. Study on the fat and total solids contents of milk supplied by different sources in Islamabad Pak. J. Agric. Sci. 23, pp: 101-106.

Athar, I.H and MA. Shah, 1994. Dairying in Pakistan, Country report. National Agricultural Research center, Pakistan agricultural Research Council Park road, P.O. NIH, Islamabad, Pakistan, pp: 78-82.

Athar. I.H. and T. Masud, 1991. Progressive farming 11, pp: 132-133 
Atherton, H.V. and J.A. Newlander, 1977. Chemistry and testing of dairy products 4th Edn. AVI Publishing Co., Westport, Connecticut, USA., pp: 421-418.

Banda, J.W., 2000. Livestock Development Program. P.O. Box 30549, Lilongwe and H-P Zerfas 3.3 Malawi Germany, pp: 56-59.

Campbell, J.R. and R.T. Marshall, 1975. The Science of Providing Milk for Man. McGrawHill Book Company, New York, pp: 49-52.

Castle, H. and J. Watkin, 1979. Compositional analysis of milk and study of its different enzymes, 11, pp: 1215-1218.

Eckles, C.H., W.B. Combs and H. Macy, 1957. Milk and milk products. 4th Edn McGraw Hill Book Company, Inc., NY, USA, 12, pp: 988-112.

Eddleman, H., 1999. Study of the Lactoperoxidase system and its functions, President, Indiana Biolab, 14045 Huff St., Palmyra, pp: 112-115.

Foltys, V., 1993. Are we ready for new standards? Nas-Chov, 4, pp: 145-146.

Gervilla, R., X. Felipe, V. Ferragut and B. Guamis, 1997. Effect of high hydrostatic pressure on Escherichia coli and Pseudomonas fluorescens strains in bovine milk. J. Dairy Sci., 80: pp: 2297-2303.

Hanjra, S.H., M. Akram and B.B. Khan, 1989. Market quality of milk in Pakistan. National Symposium on Dairy Technology held at NARC, Islamabad, Pakistan, pp: 55-59.

Ibeawachi, J.A. and D.M. Daylop, 1995. Composition and quality of fresh cow milk offered for sale in parts of plateau state Nigeria. Nigerian J. Anim. Prod., 22, pp: 81-84.

Imran, M; Khan, H; Hassan, S.S; \& Khan, R; (2008). Physiochemical characteristics of various milk samples available in Pakistan. Journal of Zhejiang University Sci. B 2008 july; 9 (7) ; pp: 546-551.

Jones, A.C., G.J.G. King, H. Fennell and D. Stone, 1957. Mon. Bull. Minist. Hlth. Lab. Serv., pp: 16:109.

Kanwal, R., T. Ahmed, I.H. Athar and B. Mirza, 2002. Comparative analysis of quality of milk collected from Rawalpindi/Islamabad-region. Pak. J. Food Sci., 12; pp: 2933.

Kazmi, Y., 1983. The Pure Food Laws Lahore Law Times Publications, Lahore, Pakistan, pp: $116-118$.

Khalil, I.A. and F. Manan, 1990. Chemistry One (Bioanalytical Chemistry) 2nd Edn., Taj Printing Press, Peshawar, Pakistan, pp: 26-30.

Kumari, K., Mangalika, U.L.P., 2008 Evaluation of Reliability of Lactometer for the Calculation of Solid Non-Fat (SNF) of Cow and Buffalo Milk. 
Lampert, L.M., 1965. Modern Dairy Products. Chemical Publishing Company, Inc., New York, USA., pp: 345-350.

Ling, E.R., 1957. Practical Dairy Chemistry. Vol. II, Philosophical Library, Inc., New York, USA., pp: 263-270

Louis, L.R., 1970, vol. 53. Milk :Its Nutritional Value at Low Cost for the People of All Ages. J. Dairy Sci., 53; pp: 1269-1302.

Malcolm, E.C. and W. Paul, 1979. Modern Milk Products. 1st Edn., Magraw Hill Brok Company, $1^{\text {st }}$ Edn, pp: 81-83.

Minard, R., 1990 "Isolation of casein, lactose \& albumin from milk" Penn state Univ., Department of Chemistry, USA . A Microscopic Approach, Pavia,_Lampan,,Kriz and Engle, Saunders, 1990. Revised 3/20/2020

Mohmood, A; Usman, S. Department of Chemistry, University of Gujrat Pakistan; Pakistan Journal of Nutrition 9 (12); 1992-1997, 2010.

Patel, R.S. and V.V. Mistry, 1997. Physicochemical and structural properties of ultra filtered buffalo milk and milk powder. J. Dairy Sci., 80; pp: 812-817.

Patel, K.J., Boghra V.R.(2018). Modification in Richmond Formula for Calculating Solidsnot-Fat/Total Solids Percentage in Cow;Asian J. Diary \& Food Res, Vol. 37(4) 2018, pp:278-282.

Pein, J., 1970. International Survey on the Composition of Milk. Int. Dairy Federal

Rao, S.R.M.; Bector, B.S. (1998). A Comparative Study on the Determination of Solidsnon-Fat in Milk by Calculations. Indian Journal of Dairy Science 1998 Vol. 33 No 1 pp: 1-6 ref. 18 .

Roadhouse, C.L. and J.L Henderson, 1950. The Market Milk Industry. 2nd Edn., Magraw Hill Brok Company, pp: 41-42. 